\title{
PENGEMBANGAN MODEL PEMBELAJARAN KESADARAN BENCANA DI SEKOLAH DASAR
}

\section{DEVELOPMENT OF DISASTER AWARENESS LEARNING MODELS IN BASIC SCHOOLS}

\author{
Syahrial Ayubi ${ }^{*}$, Kosim ${ }^{1}$, I Wayan Gunada ${ }^{1}$, Endang P Handayani ${ }^{2}$ \\ ${ }^{1}$ Program Studi Pendidikan Fisika, Jurusan Pendidikan MIPA, FKIP, Universitas Mataram \\ ${ }^{4)}$ Sekolah Dasar Negeri 6 Mataram, Jalan Caturwarga No 1 Mataram, NTB \\ *Email: syahrial_ayub@unram.ac.id
}

Diterima: 10 Juli 2019. Disetujui: 10 Juli 2019. Dipublikasikan: 31 Juli 2019

\begin{abstract}
Abstrak. Mengajar adalah pekerjaan guru sehari-hari. Namun demikian, mengajar bagaimana siswa belajar, ternyata tidaklah mudah. Penelitian ini adalah penelitian dan pengembangan (Research and Development) yang bertujuan memberikan contoh nyata bagaimana cara mengajar dan menanamkan kesadaran bencana pada masyarakat sekolah secara sederhana dan menyenangkan dengan model pembelajaran kesadaran bencana. Hasil penelitian berupa desain model pembelajaran kesadaran bencana dan struktur pembelajaran yang merupakan penerapan pendekatan saintifik pada kesadaran bencana. Penelitian ini berdasarkan pengembangan dan pengalaman tim peneliti dalam mengajar dan melakukan penelitian pada kepala sekolah, guru dan peserta didik di SD Negeri 6 Mataram dan. SD Negeri 6 Mataram merupakan pilot project dari penelitian ini dan akan diterapkan pada sekolah-sekolah lain di daerah kota, pesisir dan pegunungan di pulau Lombok. Respon kepala sekolah dan bapak ibu guru terhadap model pembelajaran kesadaran ini sangat positif, dimana $95 \%$ menyatakan sangat tertarik dan hanya 5\% yang menyatakan tertarik. Peserta didik sangat antusias dan terlibat aktif selama proses pembelajaran dan mereka merasakan manfaat yang berarti dari pembelajaran kesadaran ini. Hal ini mengindikasikan bahwa model pembelajaran kesadaran ini dapat menjadi acuan dalam menanamkan kesadaran bencana pada masyarakat sekolah.
\end{abstract}

Kata kunci: model pembelajaran, kesadaran bencana, sekolah dasar, pulau lombok

\begin{abstract}
Teaching is every teacher's daily job. Despite this, though, teaching in the way that students learn is not an easy thing to do. This research is a Research and Development, aimed to give a real life example of how a teacher can teach and embed the awareness about natural disaster in an uncomplicated and fun way, by using disaster mitigation model of teaching. The study results in one design of disaster mitigation model of teaching and a teaching structure implementing scientific approach on disaster mitigation. This research is based on the development and real life experience of the researcher team in teaching and doing observation and research on the headmaster, teachers, and students of SD Negeri 6 Mataram. SD Negeri 6 Mataram is the pilot project of this study, which in return will be implemented in other schools in the urban, coastal area, as well as mountanious area in Lombok Island. The result shows that the headmaster and the teachers' response towards disaster mitigation model of teaching had been really positive, with only $5 \%$ of the teachers claims that they are interested, whilst the other $95 \%$ claims that the study is extremely interesting for them. The students were very enthusiastic and active during the learning process. In addition, the claim to have meaningful benefit from this mitigation learning. This thus indicated that this disaster model of teaching and learning can be used as a guide or reference in embedding the awareness for natural disaster among school community.
\end{abstract}

Keywords: model of learning, disaster awareness, primary school, lombok island

\section{PENDAHULUAN}

Lombok sebagai salah satu pulau di wilayah Indonesia yang sangat rentan terjadinya gempabumi.Baru baru ini di tahun 2018 antara bulan Juli sampai Agustus pulau Lombok diguncang 4 kali gempa bumi berkekuatan besar, yaitu 29 Juli 2018 kekuatan 6,4 SR, 5 Agustus 2018 kekuatan 7 SR, 9 Agustus 2018 kekuatan 6,2 SR dan 19 Agustus 2018 berkekuatan 7 SR ditambah dengan rentetan gempa susulan yang mencapai 2500 kali. Hal ini terdampak luar biasa pada masyarakat di pulau Lombok terutama di daerah pantai, pegunungan dan perkotaan. Ditandai dengan hancurnya bangunan dan infrastruktur di daerah yang terdampak dan yang sangat memilukan adalah terdapatnya korban ratusan korban jiwa pada rentetan gempa Lombok ini. Hasil observasi dan studi pendahuluan menunjukkan bahwa kesadaran masyarakat terhadap gempa bumi sangat kurang dan kesadaran gempa bumi juga sangat kurang. Gempa bumi merupakan bencana alam yang tidak dapat diprediksi kapan terjadinya[1,2].Gempa bumi bisa terjadi tiba-tiba seperti saat bekerja, tidur, bermain, dan bahkan 
juga saat belajar disekolah. Anak-anak adalah kelompok yang paling rentan menjadi korban gempa bumi demikian juga guru dan perangkat sekolah lainnya. Maka dari itu mereka sangat perlu dibekali konsep gempa bumi, bahaya gempa bumi dan peringatan dini, proses perencanaan evakuasi untuk sekolah, tindakan penyelamatan diri dan prosedur pertolongan pertama pada korban supaya kerugian material dan jiwa dapat diminimalisir. Gempa bumi hanya merupakan salah satu jenis bencana yang kerap melanda Indonesia. Ada beberapa jenis bencana lain yaitu: tsunami, tanah longsor, banjir, kekeringan, badai dan bencana gunung api.

Mengajarkan sesuatu yang baru kepada anak-anak tentu membutuhkan metode yang tepat, efektif dan menyenangkan[3]. Penelitian ini bertujuan mengembangkan model pembelajaran kesadaran bencana bagi guru dan siswa sekolah dasar di daerah kota, pesisir dan gunung merapi rinjani di pulau Lombok. Metode yang tepat, siswa dan guru tertanam kesadaran bencanadan reflek mengambil tindakan yang tepat saat terjadi bencana serta adanya acuan struktur pembelajaran kesadaran bencana untuk guru yang akan mengajarkannya[4].

Model pembelajaran kesadaran bencana ini dikembangkan dengan menerapkan pendekatan yang mampu membuat pembelajaran efektif, inovatif, kreatif dan menyenangkan. Salah satu pendekatan yang dianggap sesuai adalah pendekatan saintifik. Pendekatan saintifik menggunakan pembelajaran penemuan (Discovery Learning) [5]. Discovery Learning merupakan suatu model pembelajaran yang melibatkan secara maksimal seluruh kemampuan peserta didik untuk mencari dan menemukan sesuatu benda, manusia atau peristiwa secara sistematis, kritis, logis, analitis sehingga peserta didik dapat merumuskan sendiri penemuannya dengan penuh percaya diri[6]. Selama proses pembelajaran, guru semestinya membantu siswa untuk aktif dalam mencari konsep, prinsip dan fakta bagi dirinya sendiri, bukan hanya memberikan ceramah dan mengendalikan kelas (teachers oriented), dengan demikian siswa akan mampu untuk membangun pengetahuannya sendiri[7].

Kesadaran bencana pada peserta didik, guru dan kepala sekolah akan muncul dari proses pembelajaran kesadaran yang dilaksanakan. Tanpa ada proses ini mustahil kesadaran bencana akan terpatri pada mereka sehingga tujuan utama untuk mencapai masyarakat sadar bencana akan sulit[8]. Selain proses pembelajaran kesadaran ini, masyarakat sekolah juga diberikan pengetahuan yang berisi : (1) pengetahuan dan tanda-tanda akan terjadi bencana, (2) dampak bencana, (3) resiko dan upaya mengurangi, (4) kesiapsiagaan menghadapi bencana, dan (5) prosedur dan alat pertolongan pertama pada korban, dengan ini diharapkan peserta didik, guru dan kepala sekolah mampu memahami tentang kebencanaan dan kesadaran nya dengan baik[9].

Untuk menjawab tantangan tersebut, sangatlah penting seorang guru mengajarkan kebencanaan dan kesadarannya lewat keterampilan proses sains. Keterampilan proses sains sebenarnya menjadi dasar pendekatan saintifik di kurikulum 2013. Salah satu kegiatan yang dapat diambil guru adalah melakukan praktek[10]. Praktek, peserta didik dapat memperoleh pengalaman langsung mengenai kebencanaan dan kesadaran. Peserta didik akan lebih mudah mengingat suatu konsep bencana jika ia melihat langsung. Peserta didik bahkan tidak hanya sekedar mengingat tetapi mengerti suatu konsep bencana jika ia mengalami sendiri. Melalui praktek, siswa dapat menemukan masalah sekaligus mencari jawaban atas masalah yang ditemukan. Masalah yang muncul melalui praktek merupakan sumber ransangan yang sangat potensial untuk belajar lebih banyak. Dengan praktek akan terjadi proses belajar yang punya kandungan ilmiah yang berbobot. Masalah akan dipecahkan sendiri lewat praktek tanpa perlu ceramah teoritis dari gurunya. Melalui praktek, siswa dapat juga dilatih untuk menggunakan metode-metode ilmiah sederhana yang sahih seperti halnya seorang ilmuwan[11].

Tulisan ini didasarkan pada hasil penelitian, pengalaman dan pengamatan pembelajaran kebencanaan di kelas menggunakan pendekatan saintifik dengan praktek[12]. Permasalahan yang menarik adalah:

(1) Bagaimana mengajarkan konsep kebencanaan dengan model pembelajaran kesadaran yang berorientasi pada siswa?

(2) Bagaimana struktur pembelajaran kesadaran yang berorientasi pada siswa?

(3) Bagaimana respon peserta didik, guru dan kepala sekolah terhadap pembelajaran kesadaran yang berorientasi pada siswa?

\section{METODE PENELITIAN}

Model pembelajaran kesadaran bencana dan struktur pembelajaran yang ditemukan merupakan hasil penelitian dan pengembangan (research and development) yang dilakukan tim peneliti. Penelitian ini sebenarnya telah dilakukan secara kontinu lebih awal selama tim peneliti bergabung di proyek peningkatan kesadaran bencana bagi peserta didik di sekolah dasar kerjasama Indonesia Jerman yang disebut DAPS (Disaster Awareness in Primary School) dari tahun 2007 sampai dengan 2013. Hasil penerapan model yang telah dirancang peneliti di berbagai tempat ini di evaluasi dan direfleksikan pada penerapan berikutnya, sehingga didapatkan model pembelajarankesadaran bencana pada saat ini[12]. Penelitian dan pengembangan atau biasa disebut dengan $\mathrm{RnD}$ digunakan untuk menghasilkan dan menguji keefektifan produk tertentu. Penelitian ini 
dilakukan dengan 4 tahapan yaitu tahap memutuskan (decide), mendesain (design), pengembangan (develop), dan mengevaluasi (evaluate) [13]. Awal penelitian ini dilakukan brainstorming, analisis konten dan kajian literatur dalam mengembangkan model pembelajaran. Salah satu hal utama yang diputuskan pada tahap ini adalah konsep bencana yang akan dijadikan model. Pada tahap desain peneliti melakukan perancangan model pembelajaran dengan 3 tahapan, yaitu kegiatan awal, inti, dan penutup yang di sinkronkan dengan pendekatan saintifik[14,15]. Tahap pengembangan peneliti terus menyempurnakan kekurangan kekurangan pada model yang telah di desain. Berdasarkan hasil evaluasi yang kontinu diharapkan didapatkan model yang terbaik dalam memberikan contoh nyata pembelajaran kesadaran bencana dengan sederhana dan sesuai dengan pendekatan saintifik.

\section{HASIL DAN PEMBAHASAN}

Pendekatan saintifik merekomendasikan 3 pembelajaran, yaitu (1) Discovery Learning, (2) Problem Based Learning dan (3) Project Based Learning. Berbeda dengan metode ceramah, fokus utama dari metode belajar menemukan adalah kegiatan peserta didik secara mandiri[16]. Memang materi dipilih dan disiapkan oleh guru, tetapi para siswa yang secara mandiri membahas suatu masalah tertentu atau guru melemparkan suatu pertanyaan tertentu di awal pembelajaran. Diskusi maupun proses kegiatan sebagian besar ditentukan sendiri oleh siswa, baik selama pelajaran di kelas maupun di dalam kelompok.

Metode ini mempunyai beberapa keunggulan, diantaranya adalah:

a) pengembangan kemandirian dan kegiatan mandiri peserta didik

b) stimulasi kemampuan merencanakan, mengorganisasi dan melaksanakan kegiatan

c) pengembangan tanggung jawab terhadap suatu kegiatan, dan

d) pengenalan metode-metode kerja dan berpikir dalam bidang penelitian.

Model discovery learning berpengaruh positif terhadap hasil belajar peserta didik [17]. Salah satu keberhasilan utama dari praktek dan teori pengajaran abad ini adalah bahwa peserta didik dianggap sebagai mitra yang bertindak dan berpikir, dan bukan lagi diharapkan untuk menguasai dan menghafal pengetahuan yang tidak ia pahami atau tidak diterangkan secara objektif. Metode belajar menemukan memungkinkan siswa untuk mengalami sendiri bagaimana caranya menemukan keterkaitan-keterkaitan baru dan bagaimana caranya meraih pengetahuan melalui kegiatan mandiri.

Tabel 1: Struktur Pengajaran Pemecahan Masalah

\begin{tabular}{|c|c|c|}
\hline No & Langkah Pengajaran & Tujuan Langkah Pengajaran \\
\hline 1. & Motivasi & $\begin{array}{c}\text { Membangkitkan rasa tertarik dan } \\
\text { keingintahuan siswa terhadap materi } \\
\text { pelajaran yang akan diajarkan }\end{array}$ \\
\hline 2. & Penjabaran masalah & Merumuskan suatu pertanyaan ilmiah \\
\hline 3. & Penyusunan opini & Perumusan hipotesis \\
\hline 4. & $\begin{array}{l}\text { Perencanaan dan } \\
\text { konstruksi }\end{array}$ & Persiapan peralatan praktek yang akan digunakan \\
\hline 5. & Praktek & Perwujudan suatu reaksi alam \\
\hline 6. & Kesimpulan & $\begin{array}{l}\text { Kesimpulan suatu prosedur pemecahan } \\
\text { masalah }\end{array}$ \\
\hline 7. & Abstraksi & Hasil ilmiah yang sah \\
\hline 8 & $\begin{array}{l}\text { Konsolidasi pengetahuan } \\
\text { melalui aplikasi dan } \\
\text { praktek }\end{array}$ & $\begin{array}{l}\text { Pengetahuan komprehensif atas suatu gejala alam dan } \\
\text { pengintegrasian hasil pendidikan }\end{array}$ \\
\hline
\end{tabular}

Sumber [18]

Model pembelajaran berbasis masalah (Problem Based Learning) adalah penyelesaian masalah terkait materi pembelajaran, bukan bagaimana guru menyampaikan materi pembelajaran. Model pembelajaran berbasis masalah dengan metode eksperimen menyediakan pengalaman autentik yang mendorong peserta didik untuk belajar aktif[19].

Model pembelajaran kesadaran dikembangkan berdasarkan pendekatan-pendekatan yang diuraikan sebelumnya. Terdapat 3 tahapan pokok pada pembelajaran kesadaran bencana ini, yaitu: (1) kegiatan awal, (2) kegiatan inti, dan (3) kegiatan pemantapan. Masing-masing kegiatan pada tahapan pokok ini mempunyai tujuan tertentu.

\section{Kegiatan Awal}

Kegiatan awal pada pembelajaran kesadaran bencana bertujuan memotivasi peserta didik sehingga peserta didik tertarik, ingin mengikuti 
materi pembelajaran kesadaran bencana yang akan dilakukan. Hal ini sangat penting dilakukan untuk memunculkan kerinduan peserta didik belajar terutama tentang kesadaran bencana. Ada banyak alternatif kegiatan yang dapat dilakukan guru untuk memotivasi peserta didik. Alternatif kegiatan yang dapat dipilih oleh guru pada kegiatan awal adalah: (1) demo sesuatu yang dibawa/guru, (2) pemutaran video, (3) bercerita/kejadian, (4) bernyanyi (sesuai dengan materi kebencanaan yang diberikan), (5) Review/melanjutkan pelajaran terdahulu yang tidak lengkap, (6) mengamati/membahas penerapan teknis di lingkungan, (7) menyajikan fenomena, (8) menggali pengetahuan awal peserta didik, dan (9) bisa juga menampilkan poster/gambar tentang bencana. Intinya dari kegiatan awal yang dirancang guru ini, peserta didik mampu secara mandiri menemukan permasalahan pembelajaran yang akan diajarkan. Bila masalah itu ditemukan sendiri oleh peserta didik diharapkan peserta didik akan tertarik dan termotivasi untuk melaksanakan pembelajaran selanjutnya.

Sebagai contoh, waktu memulai pembelajaran seorang guru bercerita:

Suatu pagi di pulau simeuleu. Sebuah pulau yang terletak $176 \mathrm{~km}$ dari lepas pantai barat kota meulaboh (NAD). Seperti biasanya, pada hari minggu anak-anak sedang bermain di pesisir pantai. Mereka tampak riang sekali. Diantara anak-anak itu tampak Fachri dan Hanafi terlihat sedang asyik bermain bola. Mereka ditemani oleh Aminah dan Siti, kedua sahabat mereka yang asyik bersenda gurau di atas sebuah batu besar. Tiba-tiba.... Bumi bergetar, "GREEKK!!! GREEKK!!! GREEKK!!!. Semua orangpun panik dan terjatuh. "GREEKK!!! BRAKK!!!, kelapa dan benda lain berjatuhan. Gempa!! Gempa!! Ada Gempa!!! Kata Fachri dan Hanafi sambil terjatuh. "Ya Allah, kenapa sepagi ini ada gempa?", kata seorang anak sambil berlari ke tempat yang lebih tinggi. "Allahu Akbar!! Ya Allah, ampuni kami!! Gempa!! Gempa !! Larii !!! Beberapa menit kemudian, ketika gempa telah berhenti... Banyak rumah-rumah penduduk roboh tidak kuat menahan getaran gempa. Tiba-tiba terdengar seseorang mengatakan "SMONG!!", Gawat!! Ayo, Hanafi. Kita harus segera pergi ke arah bukit!! Cepat!! SMONG itu adalah gelombang besar! Gelombang besar yang sudah diceritakan nenek moyang kita turun menurun! "Gelombang besar?? Aku tidak percaya!! Mana buktinya?? Memangnya ada tandatanda akan muncul SMONG??", kata Fachri sambil menunjuk ke arah bibir pantai agar Hanafi melihatnya. (SMONG adalah bahasa daerah Simeuleu untuk Tsunami). "Heiii !!! Mau kemana kau, Hanafii !!! Kembali !!!, teriak Fachri sambil melotot ke Hanafi. "Tidakk! Justru karena air lautnya surut, aku mau mengambil kerang-kerang yang ada di pantai itu. Kamu duluan aja." ucap Hanafi kepada Fachri seraya berlari ke arah laut. "Hanafiii !!! kembali ayoooo! Kita harus segera mengungsi ke arah bukit!!! Cepatlah aku tunggu di atas bukit!!", teriak Fachri sambil berlari ke arah bukit meninggalkan Hanafi. "Waah!! Kerangnya bagus-bagus!! Seperti yang ada di....", ucap Hanafi yang kemudian semakin pelan dan kemudian berubah pucat "DALAM LAUT....., ZAAZAAAA!!", tiba tiba saja datang gelombang besar dari arah laut yang kemudian menelan Hanafi dan menyerang desa tersebut.

Diharapkan dari cerita ini, peserta didik akan terpancing untuk bertanya dan pada akhir kegiatan awal ini mampu merumuskan masalah pembelajaran kesadaran bencana yang akan dilakukan.

\section{Kegiatan Inti}

Permasalahan yang muncul diakhir kegiatan awal, mengindikasikan seorang guru mulai melangkah pada kegiatan inti. Permasalahan itu jangan dijawab oleh guru, tapi cukup ditampung saja, beri penghargaan lebih baik. Guru hanya mengarahkan peserta didik, untuk menjawab permasalahan ini, kita lakukan kegiatan berikut. Pada kegiatan inti pada pembelajaran kesadaran bencana, yang perlu diperhatikan adalah sebelum terjadi bencana, saat terjadi bencana, proses penyelamatan diri dari bencana, saat sampai di daerah aman, dan saat pertolongan pertama pada korban. Alternatif kegiatan yang dapat dipilih oleh guru adalah: (1) melaksanakan praktek, (2) permainan/simulasi, (3) klasifikasi/pengelompokan, (4) Periksa peta evakuasi, (5) periksa alat teknis pertolongan pertama pada korban. Pada proses ini, peserta didik diharapkan berpartisipasi aktif dan melakukan pengamatan sebanyak mungkin. Berdasarkan penjelasan oleh siswa (tebak-dugadiskusi) dan landasan pemikiran diharapkan peserta didik mampu menarik kesimpulan sendiri. Setelah kesimpulan didapat oleh peserta didik, permasalahan yang muncul diawal kegiatan inti akan terjawab sendiri. Peserta didik yang akan merasakan sendiri jawaban-jawaban mereka diawal kegiatan inti tadi benar atau salah. Jadi tidak guru yang membenarkan atau menyalahkan. Proses ini yang membuat pembelajaran kesadaran bencana menjadi menyenangkan, membuat penasaran dan inovatif.

\section{Kegiatan Pemantapan}

Pada kegiatan pemantapan ada beberapa hal yang harus dibahas oleh guru, yaitu : (1) penerapan 
(berhubungan dengan lingkungan peserta didik), (2) menjawab pertanyaan, (3) membuat ringkasan, dan (4) memberikan pekerjaan rumah. Bila kita kaitkan alur pembelajar-an ini dengan pendekatan saintifik, sangat sesuai dengan tahapantahapannya. Ada 6 tahapan pendekatan saintifik, yaitu:(1) Mengamati, (2) Menanya, (3) Mengumpulkan Informasi, (4) Mengasosiasi, (5) Menyimpulkan, , (6) Mengkomunikasikan. Berdasarkan hasil ini, tim peneliti menemukan struktur pembelajaran kesadaran bencana adalah sebagai

Tabel 2: Struktur Pembelajaran KesadaranBencana Rekomendasi Penelitian

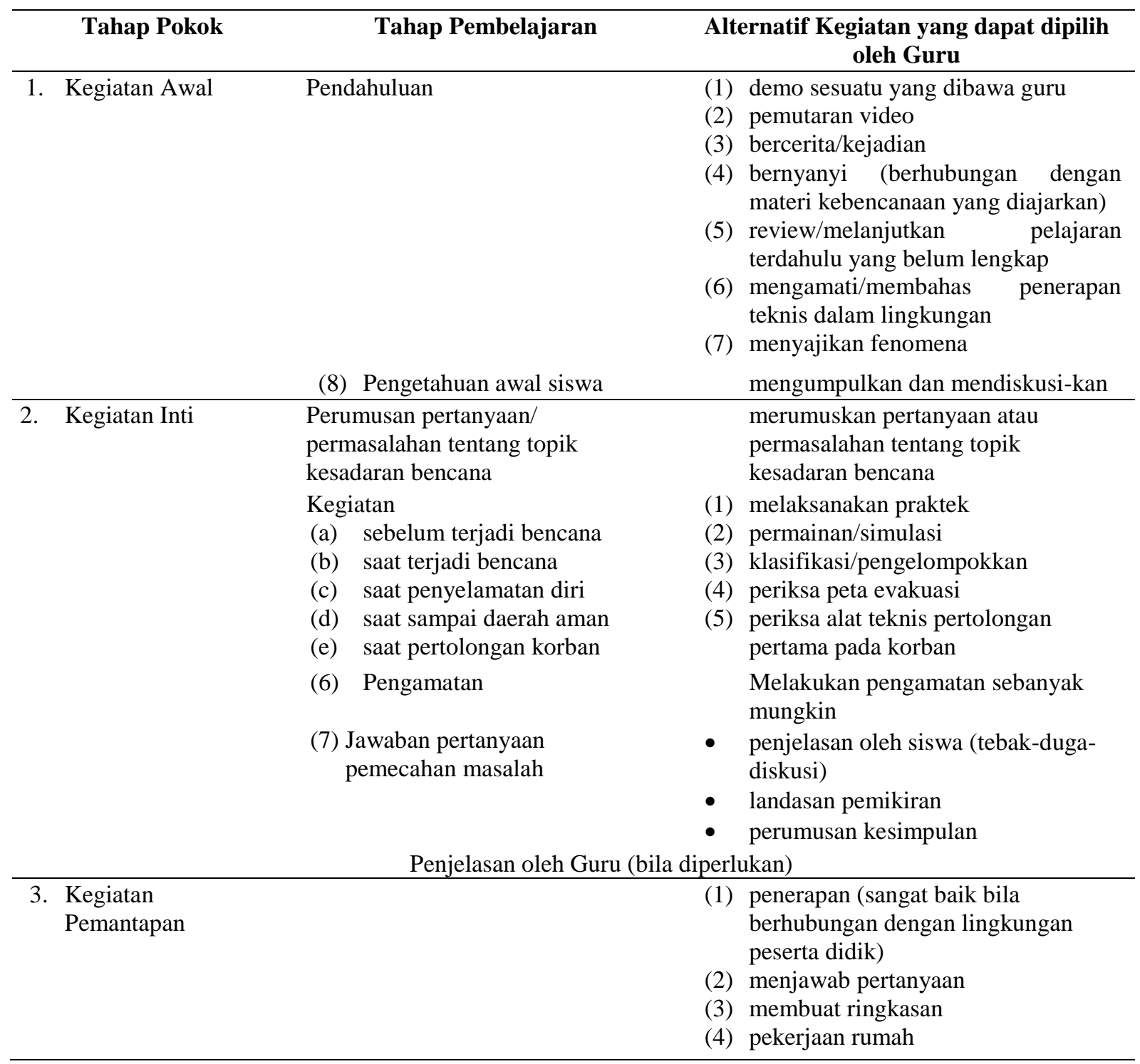

\section{KESIMPULAN}

Penerapan pendekatan saintifik/discovery learning pada model pembelajaran kesadaran bencana sangat cocok dalam pembelajaran kebencanaan. Terbukti bahwa pembelajaran ini membuat para siswa lebih memahamikonsep kebencanaan yang dipelajarinya, lebih antusias dan terlibat aktif dalam mengikuti pembelajaran tersebut. Demikian juga pada gurunya, metode ini menuntut banyak kemampuan yang harus dimiliki oleh seorang guru, misalnya guru harus menguasai materi, terbiasa berpikir logis seperti seorang ilmuwan, sikap mental yang terbuka (demokratis), cepat tanggap membaca pikiran orang lain, dan ingin selalu berkembang. Anggapan guru bahwa pendekatan saintifik membatasi kreatifitas guru menjadi terpatahkan karena ternyata pendekatan saintifik memberikan kewenangan lebih buat guru dalam mengoptimalkan kreatifitas dan inovasinya.

\section{DAFTAR PUSTAKA}

[1]. Syahrial, A. Kosim. Gunada. Tsunami. Gunung Sari West Lombok 2019: Arga Puji

[2]. Diposaptono S. Tsunami Mitigation Technology. Republic of Indonesia 
Maritime and Fisheries Agency Tsunami Mitigation Training Material 2005.

[3]. Djamarah, Teachers and Students in Educative Interaction, A Psychological Theoretical Approach, Jakarta 2005, Rineka Cipta.

[4]. UNDP, Introduction to Hazard, 2nd Edition. Disaster M Management Training Programe, Wisconsin 1995, University of Wisconsin, USA.

[5]. Irawan P.1997. Learning Theory. PAUPPAI. Jakarta: Universitas Terbuka.

[6]. Syahrial, A.Study of the Use of elementry school Science Kits in Mataram, Mataram2011, Lembaga Penelitian Universitas Mataram

[7]. Muryani, A.D., \& Rochmawati. 2015. Differences in Student Learning Outcomes Using Assisted Discovery Learning Learning Models and Without Assistance to Student Worksheets. Jurnal Pendidikan Ekonomi . 1(1): 0-216.

[8]. Klinger, Walter. 1997. Survey of Teaching Methods in Natural Sciences Erziehungswiss. Fakultat der Universtat: Erlangen-Nurnbe.

[9]. Suprapto S. 2002, Flood Disaster, Material for Disaster Power Training. Yogyakarta PSBA UGM.

[10]. Ramdhani A. 2005. Optimization of Physics Learning with the Use of Science Kits at SMP N 6 Mataram. Mataram: Press Unram,.

[11]. Hamidah, Gunawan, \& Muhammad Taufik. Effect of Media Assisted Discovery Learning Model on Physics Learning Outcomes of
Class XI Students of SMA N 1 Kediri Academic Year 2017/2018. Jurnal Pendidikan Fisika dan Teknologi. 4(1) Juni 2018.

[12]. Ivers, Baron. 2002. Multimedia Projects in Education Designing Producing and Assesing. New York: John Willey \& Sons.

[13]. Sugiyono. 2013. Qualitative Quantitative Research Methods and $R$ \& D. Bandung: Alfabeta.

[14]. Hairunnisyah Sahidu, Gunawan, Indriaturrahmi, \& Fitri Astutik. EAssessment System Design on Physics Learning at LPTK .Jurnal Pendidikan Fisika dan Teknologi, 3(2) Desember 2017.

[15]. Mubarok, C . Sulistyo, E. The application of discovery learning learning models to the learning outcomes of class $\mathrm{x}$ tav students on competency standards for installing a sound system in public high school 2 Surabaya. Jurnal Pendidikan Teknik Elektro 3 (2) 2014.

[16]. Huda, M. 2013. Teaching and Learning Model Models of Methodical and Pragmatic Issues. Yogyakarta, Pustaka Pelajar

[17]. Subrata.2001. Efforts to Improve the Quality of Learning Outcomes of Elementary Students through Science Learning with Process Skills. Laporan Penelitian STKIP Singaraja.

[18]. Syahrial, A. Kosim. Gunada. 2019. Tsunami. Gunung Sari West Lombok: Arga Puji.

[19]. Ibrahim. Muslimin. 2000. Problem Based Learning. Surabaya: University Press. 